AN ECONOMIC ANALYSIS OF HATCHING

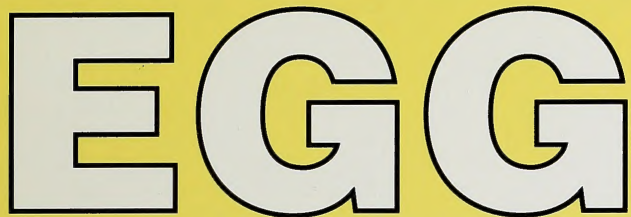

PRODUCTION IN ALBERTA
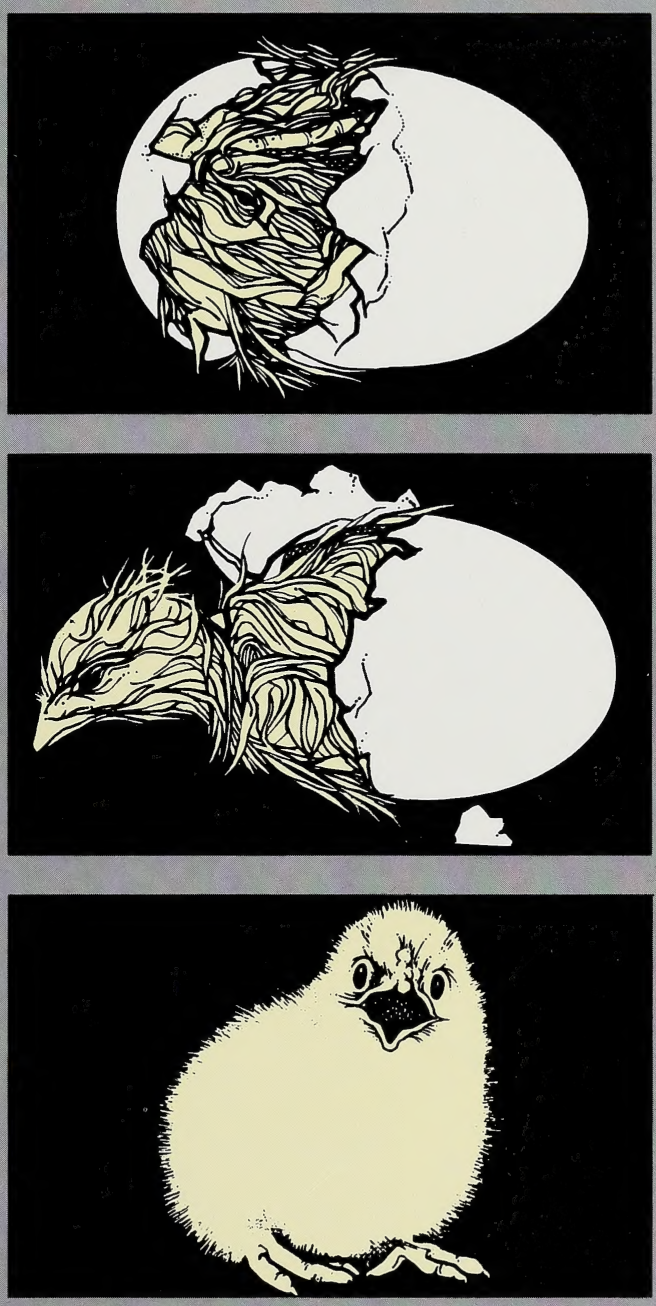
Digitized by the Internet Archive in 2015

https://archive.org/details/economicanalysis00ross 


\title{
AN ECONOMIC ANALYSIS OF HATCHING EGG PRODUCTION IN ALBERTA
}

\author{
by \\ Carlyle Ross, Darren Chase \\ and \\ Rudy Susko
}

ALBERTA AGRICULTURE

Economic Services Division

Production Economics Branch

November 1991 


\section{ACKNOWLEDGEMENT}

We wish to thank the hatching egg producers who participated in this study. Their cooperation was essential to the completion of this study.

We thank Bill Herbert for his helpful comments throughout the study. Thanks are also due to John Mason and Lyle Noel who commented on an earlier draft of this report. Finally, we express much appreciation to the field staff that collected the information over the 3-year period and the secretaries who typed the many drafts of this report.

Carlyle Ross, Head

Production Economics Branch 


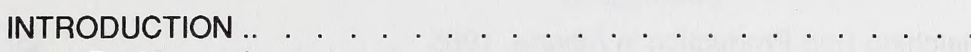

Background.

Objectives

Page

Survey Method

METHOD OF ANALYSIS . . . . . . . . . . . . . . . . . 2

HATCHING EGG PRODUCTION IN ALBERTA . . . . . . . . . . . . . 4

RESULTS OF ANALYSIS . . . . . . . . . . . . . . . . . . . 11

Production . . . . . . . . . . . . . . . . . . . . . . 11

Investment . . . . . . . . . . . . . . . . . . . . . . . 11

Gross Income . . . . . . . . . . . . . . . . . . . 11

Breeder Chick Cost. . . . . . . . . . . . . . . . . . . . 12

Feed Cost . . . . . . . . . . . . . . . . . . . . . . . 12

Labour Costs . . . . . . . . . . . . . . . . . . . . . . . . . 13

Other Variable Expenses . . . . . . . . . . . . . . . . . . . . . . 13

Fixed or Capital Costs . . . . . . . . . . . . . . . . . . . . . . . . 14

Total Production Cost. . . . . . . . . . . . . . . . . . . . . . . . . . 14

Gross and Contribution Margins . . . . . . . . . . . . . . 14

Returns to Equity and Total Investment . . . . . . . . . . . 15

SUMMARY AND CONCLUSION . . . . . . . . . . . . . . . . . 17

\section{LIST OF TABLES}

Table 1 Total Hatching Egg Production and Sales in Alberta, 1982 to 1987 . . . . . . . . . . . . . 5

Table 2 Origin of Broiler Hatching Eggs Set in Alberta, 1982 to 1987 . . . . . . . . . . . . . 10

Table 3 Disposition of Broiler Ckicks Produced in Alberta, 1982 to 1987

Table 4 Summary of Estimated Hatching Egg Farm Returns in Alberta, 1985 to 1987

\section{LIST OF FIGURES}

Figure 1 Distribution of Hatching Egg Farms by Selected

Census Divisions (C.D.) in Alberta, 1987 
Table 1 Hatching Egg Production in Alberta, $1985 \ldots 20$

Table 2 Hatching Egg Production in Alberta, 1986 . . . . . 21

Table 3 Hatching Egg Production in Alberta, $1987 \ldots \ldots$

Figure 1 Input Costs as Per Cent of Gross Income of Hatching Egg Farms in Alberta, 1985 . . . . . . . 23

Figure 2 Input Costs as Per Cent of Gross Income of Hatching Egg Farms in Alberta, $1986 \ldots 23$

Figure 3 Input Costs as Per Cent of Gross Income of

Hatching Egg Farms in Alberta, 1987 . . . . . . . 24 


\section{INTRODUCTION}

\section{Background}

Hatching egg production has become a highly specialized enterprise in commercial and broiler breeder chick production in Alberta. The success of these specialized poultry operations depends very much on their propensity to produce a high proportion of hatchable eggs for delivery to the hatcheries.

Not much is known about the existence of the hatching egg sector and the vital role it plays in the production of eggs and poultry meat in Alberta. Even less is known about the economic performance of these enterprises and what it takes to succeed. To shed some light on this subject, the Production Economics Branch of Alberta Agriculture undertook a 3-year study of hatching egg production in the province. This report summarizes the findings of the study.

\section{Objectives}

The main objectives of this study were as follows:

1. to determine the structure and production characteristics of the broiler hatching egg segment of the poultry industry in Alberta;

2. to determine the costs, returns and profitability associated with hatching egg production; and

3. to establish a profile which characterizes the top management farms.

\section{Survey Method}

In the winter of 1985,31 hatching egg producers were randomly selected from a complete list of registered commercial hatching egg producers in Alberta. The registered producers were first stratified by size of operation before making the random selections. The 31 producers chosen for the survey represented roughly one-half of the total number of registered producers in Alberta. 
Using a prepared questionnaire, each study participant was interviewed on his farm. Detailed information was obtained on the level of investment, egg production, production costs and egg sales for the 1984 production year.

Each farm record was processed in Edmonton and the initial results were mailed to producers to check for any errors and omissions. After each record was validated, the group average results were prepared. All study participants were then given an individual report on their operation, the provincial average, and a production profile of the top producing farms on the survey.

The above survey was repeated in the winters of 1986,1987 and 1988 production years with a reduced sample of 21 producers. Although the sample size remained unchanged during the latter three years, there was some turn over of the farms surveyed between 1985 and 1988. The survey results reported herein are based on the 1985, 1986 and 1987 hatching egg production years, with singular emphasis being placed on the most recent year, 1987. The management profile is being covered in a separate report.

\section{METHOD OF ANALYSIS}

Several approaches may be used to estimate the cost of production on a farm. The approach taken in this study is to report the actual enterprise cost outlays obtained from the farm records for a given production year. A computer program is utilized to summarize the data and calculate the weighted averages of all participating producers. The only imputed estimates are unpaid operator/family labour and home-grown feed values where reported. Most hatching egg producers purchased complete rations.

The economic well being of the enterprise is indicated by the per cent return to equity. Return to equity is the final residual after paying all expenses, including unpaid operator/family labour, term interest payments and depreciation. An imputed value of unpaid operator/family labour is included in the variable cost; it is based on recorded hours and estimated wage rates.

The production process for a hatching egg enterprise usually follows a 62 to 66 week cycle. In this respect, the conventional annual cost analysis is out of synchrony with the production cycle. To conform with an income tax year, yearly cost accounting is the accepted method used in farm enterprise analysis. Some cost items such as utilities, building repairs, insurances, depreciation, interest, etc., are obtained on an annual basis. On the other 
hand, with enterprises such as hatching eggs, some measures are more appropriately expressed for a given production cycle, e.g. feed cost, production, receipts and mortality.

Individual hatching egg producers are very much interested in the performance of a flock over the entire cycle. In this way, one flock can be compared to another within the same operating unit. But to evaluate flock costs and returns in terms of bird quota, and to compare performance among farms or with other enterprises on the same farm, the accounting must cover the same time period. Since the accepted standard accounting period is 52 weeks, all data which are recorded by cycle, e.g., quota, feed, production and receipts, are prorated to 52 weeks. These annualized data are then combined with the other information such as utilities, repairs, insurance and interest which are reported annually for income tax purposes, to obtain a profile of annual costs and returns. However, to meet the needs of individual producers, the final results are presented on a flock or cycle basis, as well as annual, per bird housed and per chick sold.

It bears noting that the per bird and per chick estimates describe both the cycle and the annualized enterprise results. The report emphasizes 1987 results with appropriate references to 1985 and 1986. 
There are fewer than 60 registered broiler breeder farms and four principal hatcheries in Alberta. These broiler breeder farms represent the first stage of the broiler meat production cycle in Alberta. Prior to 1982, broiler breeders independently negotiated prices with the provincial hatcheries. Production levels were also negotiated on a one-to-one basis. Because of the unregulated nature of the industry, fluctuations in broiler egg demand, and the time lags associated with supply adjustments, the industry experienced serious domestic egg supply problems. The dissatisfaction with the resulting level and stability of egg returns prompted the broiler breeders to seek enabling legislation to create a marketing board. On June 15,1982 , the Alberta Hatching Egg Marketing Board (AHEMB) came into being.

The main objectives of the AHEMB were to establish a quota system of supply management, and to negotiate hatching egg prices with the hatcheries. Other objectives of the AHEMB related to adjusting production to meet seasonal changes in demand for chicks and to ensure the availability of high quality chicks for broiler meat production. The establishment of the AHEMB was initially on a trial basis, but in the spring of 1984, after two years in operation, breeders voted in a referendum to retain the board. 
TABLE 1

TOTAL HATCHING EGG PRODUCTION AND SALES

IN ALBERTA, 1982 TO 1987

\begin{tabular}{llllll}
\multicolumn{9}{c}{ Y e a r } \\
1982 & 1983 & 1984 & 1985 & 1986 & 1987
\end{tabular}

Eggs Set

Chicks Hatched

Chicks Sold To Registered

Broiler Growers

Chicks Sold to Roaster

Growers \& in Small Lots

Chicks Exported

Chicks Destroyed $\begin{array}{lll}3,885.9 & 3,819.4 & 3,564.4\end{array}$

$3,785.8$

$3,230.4$

$3,074.8$

$1,240.0$

425.3

416.2

444.7

555.6

802.0

0.8

12.1

13.9

23.6

9.5

0

Source: Alberta Hatching Egg Marketing Board Annual Reports, 1983 to 1988. 
Unlike most marketing boards, the AHEMB can only negotiate prices; it does not have the authority to set prices. Initial producer quotas were based primarily on registered placements as of November 31, 1981. Subsequent adjustments were made to these quotas to bring production in line with market demand for broilers. Quota transfer has been a contentious issue. Prior to 1987, quota could only be transferred (sold) with the facilities. However, effective June 1987, quota could be transferred without the associated facilities.

The AHEMB initially financed its operation through a check-off of 50 cents per case of eggs shipped. In 1987 when the board joined the newly created (1986) Canadian Broiler Hatching Egg Marketing Agency (CBHEMA), the levy was raised to 0.2072 cents per settable egg. Approximately 61 per cent of the levy is retained by the board and 39 per cent rebated to the national agency.

The number of chicks placed and the timing of placement are directly dependent on the AHEMB forecast of chicken consumption in Alberta. Consequently, the board consults extensively with the processors, hatcheries, Alberta Broiler Growers Marketing Board, and federal and provincial agriculture officials. Weekly statistics are available on eggs set, eggs hatched, and the number of females placed in Alberta. From this information the board is able to establish the provincial quota of eggs set, and hence the number of breeder hens needed to meet the provincial quota.

Registered broiler breeders annually purchase between 345,000 and 387,000 day old female broiler breeder chicks from the United States. The resulting all-white broiler strains produced in Alberta are crosses or pure strains of White Rock females mated to dominant White Cornish males. Hubbards comprise about 80 per cent of the White Rock females used.

Production plans are generally based on the pullets beginning to lay at 24 weeks of age with the cycle being terminated at 59 weeks. In practice, however, depending on flock productivity and market conditions, birds may be held for a complete cycle of 62 to 66 weeks.

The eggs which the farms deliver to the four main hatcheries within the province are the primary source of day old chicks for the broiler growers. Between 1982 and 1987 the number of broiler eggs set by the hatcheries ranged from 43.0 million eggs in 1983 to 51.4 million eggs in the overly optimistic peak year of 1987 (Table 1). On average, however, just over 45 million eggs are set annually, with about 35 million chicks being hatched, resulting in a 
hatchability rate of 77.4 per cent. ${ }^{1} \quad$ Hatchability and productivity were higher in 1987 than 1986, although the recovery did not attain the levels of 1985.

The majority of broiler breeder farms in Alberta are relatively small. The authorized farm placements of day-old female breeder chicks range from a low of 1,000 females on small farms to a high which exceeds 30,000 female chicks per cycle on the largest farms. Over one-third of the placements issued annually range between 2,500 and 4,999 females, and 12.5 per cent places fewer than 2,500 female chicks. At the other extreme, 14 per cent of the placements fall in size class 10,000 to 14,999 females, with the remaining 12.5 per cent of the enterprises having 15,000 or more female chicks. The weighted average placement of female chicks is about 7,800 per farm with 27 per cent of the placements ranging between 5,000 and 9,999 females. Typically, one male chick is added for every 15 female chicks placed.

Most of the hatching egg farms, 56 per cent, are located in north-central Alberta, viz., Census Divisions 10 (13.1\%), 11 (19.7\%), 12 (8.2\%) and $13(14.8 \%)$. Twenty-one per cent of the farms are in Census Divisions 2 and 3 (Lethbridge/Fort Macleod), and 12 per cent in Census Division 5 (Figure 1).

Having estimated the annual demand for hatching eggs, the AHEMB has the very formidable task of fine-tuning the provincial quota system to accurately meet the week-to-week changes in demand for chicks. Hatching egg demand is essentially what economists call a "derived demand". It is derived from consumer demand for chicken, which information is transmitted back through the marketing/production channel of retailers/processors, broiler producers, hatcheries, and then to the hatching egg producer. Therefore, to successfully forecast weekly demand in any given week, the AHEMB must have enough eggs which, when adjusted for hatchability, will produce the exact number of chicks that will be ordered three weeks later. The hatcheries themselves do not always accurately forecast broiler chick demand. In a fully integrated broiler poultry operation it would take a minimum of 34 to 36 weeks to produce a mature broiler, starting with a day-old breeder chick. In reality, broiler breeders need to know more than a year in advance, to better establish their production plans. Confronted with these constraints, it is understandable that the provincial weekly egg supply may, on occasion, be out of balance with the corresponding weekly chick demand.

${ }^{\top}$ Hatchability is defined as the number of broiler chicks hatched per 100 eggs placed by the hatcheries. 
FIGURE 1: DISTRIBUTION OF HATCHING EGG FARMS BY SELECTED* CENSUS DIVISIONS (C.D.) IN ALBERTA, 1987.

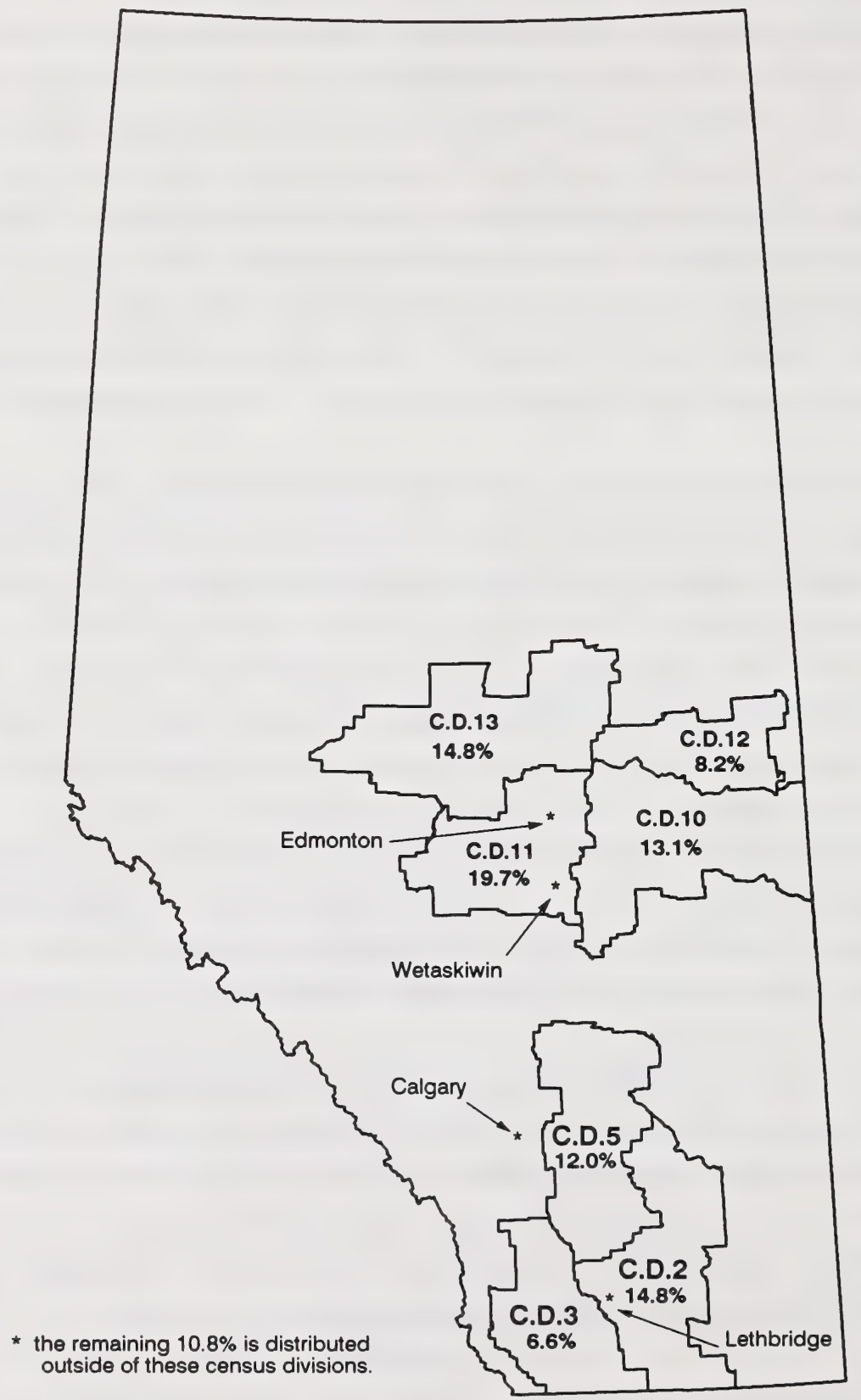


The four major hatcheries in Alberta are equipped with environmental controls which enable them to operate year-round. Indeed, as of 1987, they were considered state of the art facilities. About three-quarters of the chicks come from the Lillydale plants in Edmonton, Calgary and Lethbridge (see Figure 1). The fourth plant, belonging to Canada Packers, is located in Wetaskiwin. Hatcheries make up for an over-supply of broilers by delaying settings for brief periods. On the other hand, when supplies are short, they order eggs ahead of time. In the latter case, the AHEMB brings in eggs from other jurisdictions.

Allowance must also be made for production from small seasonal or non-commercial hatcheries which generally set eggs for the peak broiler meat season. These small hatcheries, which cater to the peak marketing season, the spring trade, can over-supply the market in any one week. Alternatively, shortages may arise from the large scale unscheduled issuance of Cornish permits to meet surges in demand. Despite the uncertainties associated with demand and supply, Alberta breeders produced 98 to 99 per cent of the eggs set by Alberta hatcheries for broiler meat production (Table 2). Over 98 per cent of the chicks hatched went to Alberta broiler growers; less than two per cent was shipped out of the province to Saskatchewan, British Columbia and Manitoba (Table 3). 
TABLE 2

ORIGIN OF BROILER HATCHING EGGS SET IN ALBERTA, 1982 TO 1987

\begin{tabular}{|c|c|c|c|c|c|c|}
\hline Origin & 1982 & 1983 & $\begin{array}{l}\text { e a r } \\
1984\end{array}$ & 1985 & 1986 & 1987 \\
\hline & \multicolumn{6}{|c|}{------------- Number of Eggs '000 ------------} \\
\hline Alberta & $44,607.8$ & $41,579.1$ & $44,636.9$ & $43,749.7$ & $45,293.7$ & $50,074.9$ \\
\hline Br. Columbia & 437.792 & 823.343 & 0 & 90.000 & 73.080 & 73.237 \\
\hline Saskatchewan & 0 & 0 & 0 & 110.000 & 113.715 & 242.746 \\
\hline Manitoba & 0 & 64.725 & 50.400 & 227.372 & 107.280 & 414.000 \\
\hline Ontario & 0 & 20.880 & 33.840 & 25.200 & 0 & 0 \\
\hline Quebec & 96.268 & 0 & 0 & 0 & 0 & 0 \\
\hline United States & 144.000 & 746.743 & 261.360 & 812.263 & 393.914 & 549.360 \\
\hline TOTAL & $45,279.9$ & $43,234.8$ & $45,025.7$ & $45,015.1$ & $45,981.7$ & $51,354.2$ \\
\hline Alberta (\%) & 98.5 & 96.1 & 99.1 & 97.2 & 98.5 & 98.5 \\
\hline
\end{tabular}

Source: Alberta Hatching Egg Marketing Board Annual Reports, 1983 to 1988.

TABLE 3

DISPOSITION OF BROILER CHICKS

PRODUCED IN ALBERTA, 1982 TO 1987

\section{Sales}

Destination

1982

$\begin{array}{cc}\text { Ye a r } \\ 1983 & 1984\end{array}$

1985

1986

1987

Number of Chicks ' 000

$\begin{array}{lrrrrrr}\text { Alberta } & 33,987.8 & 32,325.4 & 34,535.3 & 34,628.2 & 34,722.0 & 39,539.2 \\ \text { Br. Columbia } & 989.269 & 122.967 & 121.163 & 137.379 & 213.383 & 267.750 \\ \text { Saskatchewan } & 217.542 & 245.725 & 255.851 & 248.964 & 313.881 & 503.176 \\ \text { Manitoba } & 32.744 & 72.444 & 38.976 & 58.386 & 28.292 & 45.327 \\ \text { Other } & 0.462 & 9.026 & 0 & 0 & 0 & 0\end{array}$

TOTAL

Alberta (\%)
$35,227.817 \quad 35,775.562$

96.5

98.6
$34,951.29$

98.8
$35,072.929$

99.9
$35,277.556$

98.4

Source: Alberta Hatching Egg Marketing Board Annual Reports, 1983 to 1988. 


\section{RESULTS OF ANALYSIS}

\section{Production}

Typically the breeder farms on the study were in business 11 to 13 years. Their primary goal was to produce the maximum number of saleable chicks from their annual quota. The farms carried one to two flocks with a total population housed in 1987 averaging 8,700 hens, almost double the 1985 group survey results. Egg production as reflected by the number of hatching eggs sold, averaged 9.74 dozen eggs per hen (32.5 per cent of a case), down four per cent from the previous two years. Correspondingly, hen productivity over the productive life of the bird for 1987 was estimated at 3.14 eggs per hen per week in contrast to 3.3 eggs in the two preceding years (See Appendix Tables 1, 2 and 3).

Hatchability, defined as the number of eggs hatched over the number of eggs sold, was 78.2 per cent in 1987 , down by 1.56 percentage points from the peak year 1985 . Saleable chick production which averaged 85.63 chicks per bird housed, exceeded the 1986 saleable chick production, but was still almost one percentage point below that of 1985 . Hen mortality in 1987 was estimated at 15.1 per cent, more than two percentage points higher than 1985.

Investment

The total investment in hatching egg farms was estimated at $\$ 263,590$ per farm, or $\$ 30.30$ per hen housed. Buildings comprised 80 per cent of the investment, machinery and equipment 17 per cent, and land ${ }^{1}$ and supplies three per cent. Buildings and machinery were 9 to 10 years old. The debt to equity ratio was 0.66 with overall equity estimated at 60.3 per cent, roughly the same as 1985 .

\section{Gross Income}

Hatching egg revenues ( 88 - 89 per cent) came mainly from the sale of hatching eggs. In two of the three years under review, 10 to 11 per cent of egg revenues was derived from flock disposal and the private sale of(breaking) eggs .

\footnotetext{
${ }^{1}$ Building site.
} 
Between 1984 and August 1986, inclusive, the price of saleable chicks was fairly stable at about 25.5 cents per chick. ${ }^{1}$ After August 1986, the chick price rose by one cent to 26.5 cents, where it remained unchanged for the rest of the study period. When chick sales were combined with other receipts, the total income per chick sold was 29.66 cents in 1987, which was the average for the 3-year period. Marketing fees and freight were not deducted from the price, but were included in the variable cost.

Due to the role of the board in negotiating prices, there was little difference in income per chick among producers. Indeed over the 3-year period under study, gross income or revenue per bird housed slightly varied between $\$ 24.80$ in 1986 and $\$ 25.40$ in 1987 . However, for a given quota, the total returns on individual farms was affected by such critical factors as hatchability, mortality, feed and overall management. As well, there was a significant increase in breeder chick placements in 1987 from the two previous years. Annual gross income in 1987 averaged $\$ 185,906$ per farm, almost twice as much as 1985 .

\section{Breeder Chick Cost}

Most hatching egg producers plan on a replacement cycle of 62 to 66 weeks, after which time the hens are slaughtered and replaced by a new flock of pullets. The average cycle for survey flocks in 1987 was 62 weeks up from 61 weeks in 1985 and 1986 . Breeder chick cost was a significant part of total hatching egg cost, accounting for about 9 to 10 per cent of income in 1986 and 1987, and 8 per cent in 1985. Only feed and labour costs were more significant. The average chick price increased over the 3-year period from $\$ 2.00$ per chick in 1985 to $\$ 2.37$ in 1987.

Feed Cost

Undoubtedly, the economic success of hatching egg enterprises greatly depends on a proper feeding program. Expenditure on feed is the largest annual cost, comprising 48 per cent of the variable cost and 40 per cent of total production cost in 1987. It is the price as well as the quantity of feed used which affect the total cost of feed.

'Hatching egg producers sell eggs to the hatcheries, but they are paid on the basis of the number of saleable chicks produced. 
Feed grain prices significantly declined during the 1985 - 1987 period from an average of $\$ 129$ per tonne in 1985 Quarter I to $\$ 58$ per tonne in 1987 Quarter IV. At the same time, average feed costs varied between $\$ 204$ per tonne in 1985 and $\$ 190$ per tonne in 1986 . This blend price included the cost of purchased complete rations, home grown feeds and delivery charges. For each income dollar received, 36 to 38 cents were spent on feed.

Annual feed use was estimated at 46 to 47 kilograms per hen. The corresponding feed conversions in terms of saleable chicks varied between 0.54 kilograms per chick in 1985 and 1987, and 0.57 kilograms in 1986. However, due to declining feed grain prices from 1985 through 1987, the feed cost during the 3-year period was about 11 cents per saleable chick or $\$ 9$ to $\$ 10$ per bird housed.

\section{Labour Costs}

Three classes of labour inputs were identified in the study, operator, unpaid family and hired labour. In 1987, almost 71 per cent of the labour was contributed by the operator and family. As the operator and family are not usually paid as such, their work hours were valued at the average wage rate of the poultry industry. The operator and unpaid family labour wage rates were the same in $1985 / 86$ at $\$ 7.00$ and $\$ 4.00$ per hour, respectively, rising to $\$ 7.50$ and $\$ 4.50$ per hour in 1987.

Total labour hours per. 100 birds housed ranged from a high of 93 hours in 1985 to 68 and 56 hours, respectively, in 1986 and 1987. Alternatively, over the 3-year period 1985 to 1987 , breeder farms required 10.8 hours, 8.3 hours, and 6.5 hours, respectively, to produce 1,000 saleable chicks. Total labour cost per bird housed declined from 5.5 cents in 1985 to 4.3 cents in 1986 and 1987. Similarly, labour costs per chick steadily declined from 6.38 cents in 1985 to 5.0 cents in 1987. Labour accounted for 17 per cent of gross income in 1986 and 1987, down from 22 per cent in 1985.

\section{Other Variable Expenses}

Other variable expenses included medication, barn supplies, marketing fees, freight, fuel, oil, lube, utilities, repairs and operating interest. These expenses are actual cash outlays made during the year by the operator, and appropriately allocated to the hatching egg business. Annual expenses varied between 4.7 cents per saleable chick in 1986 and 3.6 cents per saleable chick in 1987 . Utilities were the most significant element in this expenditure class. 


\section{Fixed or Capital Costs}

Fixed or capital costs are those annual expenses which must be met regardless of the level of production. They are the costs associated with resource ownership. Insurance, taxes, rent, depreciation and term interest payments are considered to be fixed costs.

Depreciation was based on the original or purchased cost of the asset. The current value of farm assets was obtained by updating original cost with a net inflation index. ${ }^{1}$ Buildings were depreciated at an average annual rate of 5 per cent, and machinery at 10 per cent.

Only actual interest payments are reported. These interest payments on long term debt corresponded to an average annual interest rate of 11.6 per cent in 1987, and 14.1 and 10.9 per cent in 1985 and 1986, respectively.

Fixed costs per bird housed varied between $\$ 3.26$ in 1986 and about $\$ 4.00$ in 1985 and 1987. Almost 18 per cent of the 1987 total production cost was due to fixed costs, compared to 14.4 per cent and 16.1 per cent in 1986 and 1985, respectively. Moreover, these costs appropriated approximately 16 per cent of income in 1987 and 1985, and 13 per cent in 1986.

Total Production Cost

Overall, total production cost was $\$ 23.11$ per bird housed in 1987 compared to $\$ 24.76$ and $\$ 22.57$ per bird in 1985 and 1986, respectively. However, on a per chick basis, total cost per chick declined by about 6 per cent between 1985 and 1987. A summary of input costs as a per cent of gross income is given in Appendix Figures 1, 2 and 3.

\section{Gross and Contribution Margins}

The gross margin or return over cash expenses provides a measure of cash-flow in the business. It also indicates the income that is available for operator and family labour, debt retirement, capital purchases and profit. The gross margin fluctuated between 6.60 cents per saleable chick in 1987 and 8.79 cents per saleable chick in 1986 . Gross margin per bird housed was $\$ 5.65$ in 1987 , down almost 22 per cent from 1986 (Table 4).

${ }^{1}$ The net index is derived by adjusting the inflation rate by the corresponding depreciation rate (eg. $1.10 \div 1.05=1.048)$. 
The contribution margin or gross return is taken to be the minimum return necessary for the farm to stay in business during the short term. It is simply the income left over for fixed expenses, debt retirement, capital purchases and profits. In other words, it is the return over the variable costs. This margin remained positive over the 3 -year period rising from 5.02 cents per saleable chick in 1985 to 7.45 cents in 1987 . Alternatively, the contribution margin rose from $\$ 4.34$ per bird housed in 1985 to $\$ 6.38$ in 1987.

Returns to Equity and Total Investment

The return to equity and management is that final residual remaining after all expenses have been subtracted from the gross income. It is the overall measure of the economic well being of the farm enterprise. The dollar returns to equity in 1987 amounted to 2.67 cents per chick sold or $\$ 2.30$ per bird housed. While these returns were virtually the same as in 1986 , they were more than six times greater than the 1985 returns of 0.42 cents and 37 cents, respectively. Expressed as a per cent, the average annual return to equity on hatching egg farms steadily increased from 2.2 per cent in 1985 to 12.6 per cent in 1987 (See Table 4).

When the final residual is expressed as a per cent of gross income or total sales as opposed to the rate of return to business equity, it is called profit. The hatching egg farms surveyed posted profits ranging from 1.5 per cent in 1985 to just over 9 per cent in 1986 and 1987.

As with return to equity, average return on investment also increased over the three years under review. Study participants reported returns on investment of 6.9 per cent, 11.1 per cent and 12.2 per cent respectively, in 1985, 1986 and 1987. 
TABLE 4

SUMMARY ${ }^{\top}$ OF ESTIMATED HATCHING EGG

FARM RETURNS IN ALBERTA, 1985 TO 1987

\begin{tabular}{lccr}
\hline & \multicolumn{3}{c}{ Year } \\
& 1985 & 1986 & 1987 \\
\hline & --1 & $-\$ /$ Bird Housed & ----- \\
H. Total Investment & 27.69 & 27.95 & 30.30 \\
I. Debt & 10.85 & 7.31 & 12.04 \\
J. Equity & 16.84 & 20.64 & 18.26
\end{tabular}

A. Gross Income (Total Sales)

25.13

24.85

25.40

D. Depreciation

2.09

2.14

2.29

E. Term Loan Interest

1.53

0.80

1.40

B. Operator \& Family Labour

3.62

2.78

1.06

G. Total Production Cost

24.76

22.56

23.10

C. Total Variable Cost

20.79

19.30

19.02

K. Gross Margin $(B+D+M)$

6.08

7.21

5.65

L. Contribution Margin (A-C)

4.34

5.55

6.38

M. Profit or Return to Equity (A-G)

0.37

2.29

2.30

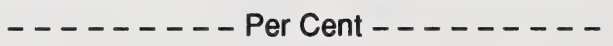

Interest $(E \div 1)$

Return on Investment $[(E+M) \div A]$

Return to Equity $(\mathrm{M} \div \mathrm{J})$

Profit $(M \div A)$
14.10

6.86

2.20

1.47
10.94

11.06

11.09

9.22
11.63

12.21

12.60

9.06

1 See Appendix Tables 1, 2 and 3. 


\section{SUMMARY AND CONCLUSION}

Hatching egg production is a highly specialized phase of broiler meat production. There are fewer than 60 registered hatching egg farms in Alberta. Most of these farms are small and mainly located in north central and southern Alberta. Since the creation of the AHEMB in 1982 , the industry has overcome most of its supply/demand problems which were common prior to the creation of the board. The board controls supply through the use of quotas and negotiates prices with the four major hatcheries.

Hatching egg demand is derived from consumer demand for chicken meat. The annual provincial quota is set according to estimates of boiler meat consumption in Alberta. Considering the intermediaries in the marketing/production channel, and the long lead time which breeders need to better establish production plans, the board was successful in managing supply and stabilizing producer incomes. Alberta broiler breeder farms now account for 98 to 99 per cent of the broiler chickens and broiler meat marketed in Alberta.

These breeder farms purchase day old broiler breeder chicks, mainly Hubbards, from the U.S. Between 347,000 and 387,000 female breeder chicks, pure White Rock strains, are imported. Over 45 million eggs are set annually, with about 35 million chicks being hatched.

Breeders are paid on the basis of eggs hatched or saleale chicks. Therefore, financial success very much depends on the maximum number of hatchable eggs delivered to the hatcheries as well as the cost of producing those eggs.

Survey results indicate that despite their small size, most breeder operations in Alberta are profitable. However, productive efficiency seems to be trending downwards. Egg production averaging 9.74 dozen eggs per bird in 1987, was four percentage points below the two previous years. Hatchability was also lower in 1987 than in 1985, i.e. 78.22 per cent versus 79.78 per cent.

Labour productivity significantly improved from 93 hours per 100 birds housed in 1985 to 56 hours per 100 birds housed in 1987. Similarly unit labour cost declined despite a 28 per cent increase in wage rates over the same time period.

Feed per bird was similar in 1987 as in 1985 , but slightly lower than in 1986 . Mortality rates seemed to be quite high, ranging from 12.7 per cent in 1985 to 16.2 per cent in 1986 . 
In spite of the foregoing, hatching egg farms reported positive gross margins or returns over cash expenses throughout the 3-year study. These returns were significantly lower in 1987 relative to 1985 and 1986 . In contrast, between 1985 and 1987, the contribution margin or return over variable costs increased by 47 per cent. This increase was mainly due to declining labour and utility costs. Returns to equity and management, the difference between gross income and total production cost were positive throughout the study period, rising from 2.2 per cent in 1985 to 12.6 per cent in 1987. Return on investment likewise steadily increased from 6.9 per cent to 12.2 per cent during the same time period. An overall summary of the results is provided in Appendix Tables 1, 2 and 3, and Appendix Figures 1, 2, and 3.

It is clear from the study results that the hatching egg industry in Alberta is economically viable. Production trends on the farms surveyed indicate that there is room for increased productivity and cost cutting. This report does not examine the role of management, which is being evaluated in a separate document. However, since the board is responsible for marketing the hatching eggs, broiler breeders can improve their net returns by striving to increase productivity and reduce production cost. Such efficiency increases can come from greater attention to feed use and chick mortality. Changing bilateral and multilateral trading rules could have serious implications for this industry. Such an evaluation is beyond the scope of this study. Further research is needed to address the issue of trade impacts. 
APPENDIX

RETURNS AND COSTS OF

HATCHING EGG PRODUCTION

IN ALBERTA

$1985-1987$ 
Egg Sales

Other Receipts

A. GROSS INCOME

Chick Costs

Feed Costs

Medication

Barn Supplies

Mktg. Fees \& Freight

Fuel, Oil \& Lube

Utilities

Machinery \& Bldg. Repairs

Operating Interest

Other Expenses

Hired Labour

B. Family Labour

Labour Costs

C. TOTAL VARIABLE COSTS

Insurance \& Taxes

Rent

D. Depreciation

E. Interest (Capital Loans)

F. TOTAL CAPITAL COSTS

G. PRODUCTION COSTS $(\mathrm{C}+\mathrm{F})$

GROSS MARGIN $(A+B+D-G)$

CONTRIBUTION MARGIN $(A-C)$

RETURN TO EQUITY (A-G)

Buildings

Machinery

Land

TOTAL INVESTMENT

EQUITY

$230.54 \mathrm{hrs}$

2360.55 hrs

$\$ 5.96 / \mathrm{hr}$

$\$ 2.00 /$ chick

$\$ 204.11 /$ tonne

7.57 years

6.55 years

$60.81 \%$

$\begin{array}{llll} & & \text { PER } & \text { PER } \\ \text { CYCLE } & \text { YEAR } & \text { BIRD } & \text { CHICK } \\ \text { TOTAL } & \text { TOTAL } & \text { HOUSED } & \text { SOLD }\end{array}$

$\begin{array}{rrrr}98,631.67 & 85,337.97 & 22.09 & 25.55 \\ 13,557.82 & 11,828.85 & 3.04 & 3.51 \\ 112,189.49 & 97,166.82 & 25.13 & 29.06\end{array}$

$9,375.57$

$42,419.29$

385.45

$2,097.87$

$2,272.88$

$1,571.45$

$5,302.12$

$2,199.88$

$1,492.99$

$1,082.54$

$8,129.19$

$36,713.79$

339.47

$1,916.00$

$1,967.65$

$1,387.21$

$4,512.99$

$1,898.04$

$1,208.43$

911.65

2.10

2.43

$8,459.34$

$16,157.25$

$7,030.89$

$14,354.71$

9.50

0.09

0.47

0.51

0.35

1.19

0.49

0.33

0.24

10.99

0.10

0.54

0.59

0.41

1.37

0.57

0.39

0.28

$\begin{array}{rrrr}8,459.34 & 3.62 & 2.19 \\ 16,157.25 & 14,354.71 & 3.62 & 4.19\end{array}$

$24,616.59$

$21,385.60$

5.51

6.38

$92,816.63$

$80,370.02$

20.79

24.04

\begin{tabular}{rccc}
$1,347.74$ & $1,154.92$ & 0.30 & 0.35 \\
218.93 & 179.65 & 0.05 & 0.06 \\
$9,347.16$ & $8,016.09$ & 2.09 & 2.42 \\
$6,839.54$ & $5,600.50$ & 1.53 & 1.77 \\
\hline $17,753.37$ & $14,951.16$ & 3.98 & 4.60 \\
\hline $110,570.00$ & $95,321.18$ & 24.76 & 28.64
\end{tabular}

$27,123.90$

$24,216.44$

6.08

7.03

$19,372.86$

$16,796.80$

4.34

5.02

$1,619.49$

$1,845.64$

0.36

0.42

$99,997.80$

22.40

5.13

25.90

$22,904.72$

0.17

5.93

748.53

$123,651.05$

27.69

0.19

$75,188.52$

16.84

19.48
Years Farming

Number of Flocks

Cycle (weeks)

Bird Quota

Chicks Purchased (placed)

Avg. No. of Birds Housed

Egg Production

Eggs Set

Eggs Hatched

No. of Saleable Chicks

Bird Productivity (eggs/wk) ${ }^{\top}$

Hatchability (\%)

Mortality (\%)

Labour (hours)

Feed $(\mathrm{kg})$

Feed (kg/doz. eggs produced)
12.59

1.59

60.89

$\begin{array}{ll}5,575.00 & 4,839.69 \\ 4,677.00 & 4,051.41 \\ 4,464.86 & 3,862.15\end{array}$

$545,463.06$

$514,270.94$

$410,267.41$

$386,064.00$

$471,126.29$
$444,420.07$
$354,416.45$
$333,829.40$

207.823 .94
0.93

46.55

0.011

$\begin{array}{rl}122.17 & 1.41 \\ 115.18 & 1.33 \\ 91.89 & 1.06 \\ 86.47 & 1.00 \\ & \\ & \\ & \\ 0.93 & 0.011 \\ 46.55 & 0.54\end{array}$

4.57

1 From 24 weeks of age. 
HATCHING EGG PRODUCTION IN ALBERTA, 1986

Egg Sales

Other Receipts

A. GROSS INCOME

\section{Chick Costs}

Feed Costs

Medication

Barn Supplies

Mktg. Fees \& Freight

Fuel, Oil \& Lube

Utilities

Machinery \& Bldg. Repairs

Operating Interest

Other Expenses

Hired Labour

B. Family Labour

Labour Costs

C. TOTAL VARIABLE COSTS

Insurance \& Taxes

Rent

D. Depreciation

E. Interest (Capital Loans)

F. TOTAL CAPITAL COSTS

G. PRODUCTION COSTS $(\mathrm{C}+\mathrm{F})$

GROSS MARGIN $(A+B+D-G)$

CONTRIBUTION MARGIN (A-C)

RETURN TO EQUITY (A-G)
$\$ 2.10 /$ chick $\$ 189.85 /$ tonne

1087.85 hrs $1843.63 \mathrm{hrs}$

$\$ 6.31 / \mathrm{hr}$

8.71 years

8.14 years

$\begin{array}{cccc} & & & \\ \text { CYCLE } & \text { YEAR } & \text { BIRD } & \text { PER } \\ \text { TOTAL } & \text { TOTAL } & \text { HOUSED } & \text { CHICK } \\ & \text { SOLD }\end{array}$

$$
105
$$

$105,175.28$

$90,436.94$

21.03

25.62

$124,258.29$

$106,833.81$

24.85

30.27

$11,118.29$

$44,598.58$

656.44

678.30

$3,100.18$

$1,757.11$

$6,071.67$

$2,222.50$

$2,093.13$

$2,864.69$

$9,582.64$

$38,388.41$

562.41

594.59

$2,625.63$

$1,537.59$

$5,138.94$

$1,850.94$

$1,829.12$

$2,448.41$

2.22

8.92

2.71

$7,503.87$

$13,885.34$

$6,557.96$

$11,948.77$

0.13

10.86

0.16

0.14

0.17

0.76

$0.35 \quad 0.43$

0.43
1.48

0.54

0.44

0.54
0.51

0.42

0.70

- . - . -

0.57

1.83

3.38

$21,389.2$

$18,506.73$

2.78

$-\overline{5}$

$------$

- $--\overline{3}, 065$.

4.28

$---$

$\begin{array}{rrrr}1,538.52 & 1,315.76 & 0.31 & 0.37 \\ 60.43 & 53.53 & 0.01 & 0.01 \\ 10,723.90 & 9,263.86 & 2.14 & 2.61 \\ 4,000.35 & 3,409.66 & 0.80 & 0.97\end{array}$

\section{- - - - -}

$16,323.20$

$14,042.81$

3.26

3.98

$112,873.30$

$97,108.22$

22.567

27.50

$35,994.23$

$27,708.19$

$30,938.22$

$23,768.40$

7.21

8.76

$11,384.99$

$9,725.59$

5.54

6.75

2.77

$\begin{array}{rrr}108,260.92 & 21.64 & 26.37 \\ 27,123.29 & 5.42 & 6.61 \\ 4,397.06 & 0.88 & 1.07 \\ 139,781.27 & 27.95 & 34.05 \\ 103,234.21 & 20.64 & 25.15\end{array}$

$73.85 \%$

Years Farming
Year

Number of Flocks

Cycle (weeks)

12.59

1.47

60.93

Bird Quota

Chicks Purchased (placed)

Avg. No. of Birds Housed

Egg Production

Eggs Set

Eggs Hatched

No. of Saleable Chicks

Bird Productivity (eggs 'wk ${ }^{\prime}$

Hatchability (\%)

Mortality (\%)

Labour (hours)

Feed $(\mathrm{kg})$

Feed (kg/doz. eggs produced)

\subsection{5 .00 \\ $5,289.88$ \\ $5,001.89$}

607.787 .17

$556,904.35$

$436,803.82$

$410,521.65$

$479,152.98$

$377,257.74$

$352,878.00$

121.51

111.34

87.33

82.07

1.48

1.36

1.06

1.00

- From 24 weeks of age. 
Egg Sales

Other Receipts

A. GROSS INCOME

Chick Costs

Feed Costs

Medication

Barn Supplies

Mktg. Fees \& Freight

Fuel, Oil \& Lube

Utilities

Machinery \& Bldg. Repairs

Operating Interest

Other Expenses

Hired Labour

B. Family Labour

Labour Costs

C. TOTAL VARIABLE COSTS

Insurance \& Taxes

Rent

D. Depreciation

E. Interest (Capital Loans)

F. TOTAL CAPITAL COSTS

G. PRODUCTION COSTS $(\mathrm{C}+\mathrm{F})$

GROSS MARGIN $(A+B+D-G)$ CONTRIBUTION MARGIN $(A-C)$ RETURN TO EQUITY (A-G)

Buildings
Machinery
Land
TOTAL INVESTMENT

$\$ 2.37 /$ chick $\$ 198.47 /$ tonne

$2885.56 \mathrm{hrs}$ 1200.25 hrs

$\$ 7.63 / \mathrm{hr}$

9.75 years

8.92 years

$60.28 \%$

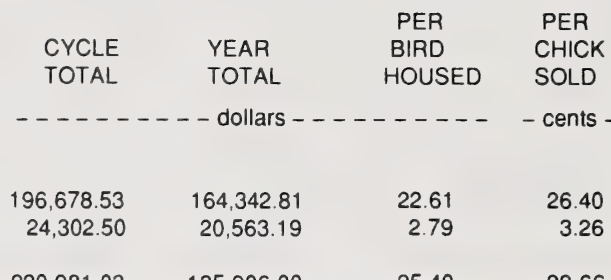

$\begin{array}{llll}220,981.03 & 185,906.00 & 25.40 & 29.66\end{array}$

$\begin{array}{rrrr}21,464.56 & 18,084.11 & 2.47 & 2.88 \\ 79,999.33 & 67,078.16 & 9.20 & 10.74 \\ 1,533.20 & 1,266.25 & 0.18 & 0.21 \\ 1,792.94 & 1,511.00 & 0.21 & 0.24 \\ 3,818.81 & 3,147.89 & 0.44 & 0.51 \\ 1,966.88 & 1,660.00 & 0.23 & 0.26 \\ 7,909.95 & 6,586.88 & 0.91 & 1.06 \\ 4,543.43 & 3,831.69 & 0.52 & 0.61 \\ 1,267.09 & 1,018.44 & 0.15 & 0.17 \\ 3,943.80 & 3,254.87 & 0.45 & 0.53\end{array}$

$\begin{array}{llll}28,000.28 & 22,883.34 & 3.22 & 3.76\end{array}$

$9,248.73 \quad 8,274.31 \quad 1.06 \quad 1.24$

- - - - - - - - - - - - - - - - - -

$\begin{array}{llll}37,249.01 & 31,157.65 & 4.28 & 5.00\end{array}$

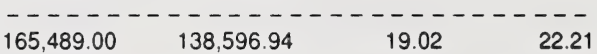

\begin{tabular}{rrrr}
$3,428.79$ & $2,921.63$ & 0.39 & 0.46 \\
19.57 & 18.13 & 0.00 & 0.00 \\
$19,957.57$ & $16,683.82$ & 2.29 & 2.68 \\
$12,160.96$ & $10,271.34$ & 1.40 & 1.63 \\
\hline
\end{tabular}

$35,566.89 \quad 29,894.92 \quad 4.09 \quad-477$

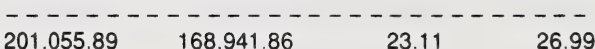

$\begin{array}{llll}49,131.44 & 41,922.27 & 5.65 & 6.59 \\ 55,492.03 & 47,309.06 & 6.38 & 7.45\end{array}$

$\begin{array}{llll}19,925.14 & 17,414.14 & 2.29 & 2.67\end{array}$

$\begin{array}{lrr}211,223.94 & 24.28 & 28.35\end{array}$

$\begin{array}{lll}43,686.24 & 5.02 & 5.86\end{array}$

$\begin{array}{lll}8,679.69 & 1.00 & 1.17\end{array}$

$\begin{array}{lll}263,589.87 & 30.30 & 35.38\end{array}$

$158,880.12 \quad 18.26 \quad 21.33$

\begin{tabular}{|c|c|c|c|c|}
\hline Years Farming & 10.50 & & & \\
\hline Number of Flocks & 2.06 & & & \\
\hline Cycle (weeks) & 62.24 & & & \\
\hline Bird Quota & $9,848.44$ & $8,234.41$ & & \\
\hline Chicks Purchased & $9,038.19$ & $7,608.03$ & & \\
\hline Avg. No. of Birds Housed & $8,699.63$ & $7,313.86$ & & \\
\hline Egg Production & $1,016,647.50$ & $855,557.00$ & 116.86 & 1.36 \\
\hline Eggs Set & $984,442.25$ & $827,076.10$ & 113.16 & 1.32 \\
\hline Eggs Hatched & $769,994.00$ & $647,681.62$ & 88.51 & 1.03 \\
\hline No. of Saleable Chicks & $744,950.99$ & $626,276.82$ & 85.63 & 1.00 \\
\hline Bird Productivity (eggs/wk) ${ }^{\top}$ & 3.14 & & & \\
\hline Hatchability (\%) & 78.22 & & & \\
\hline Mortality (\%) & 15.10 & & & \\
\hline Labour (hours/yr) & $4,085.81$ & & 0.56 & 0.006 \\
\hline Feed (kg) & $403,078.00$ & & 46.33 & 0.54 \\
\hline Feed $(\mathrm{kg} / \mathrm{doz}$. e & 4.76 & & & \\
\hline
\end{tabular}

\footnotetext{
- From 24 weeks of age.
} 
FIGURE 1: INPUT COSTS AS PER CENT OF GROSS INCOME OF HATCHING EGG FARMS IN ALBERTA, 1985

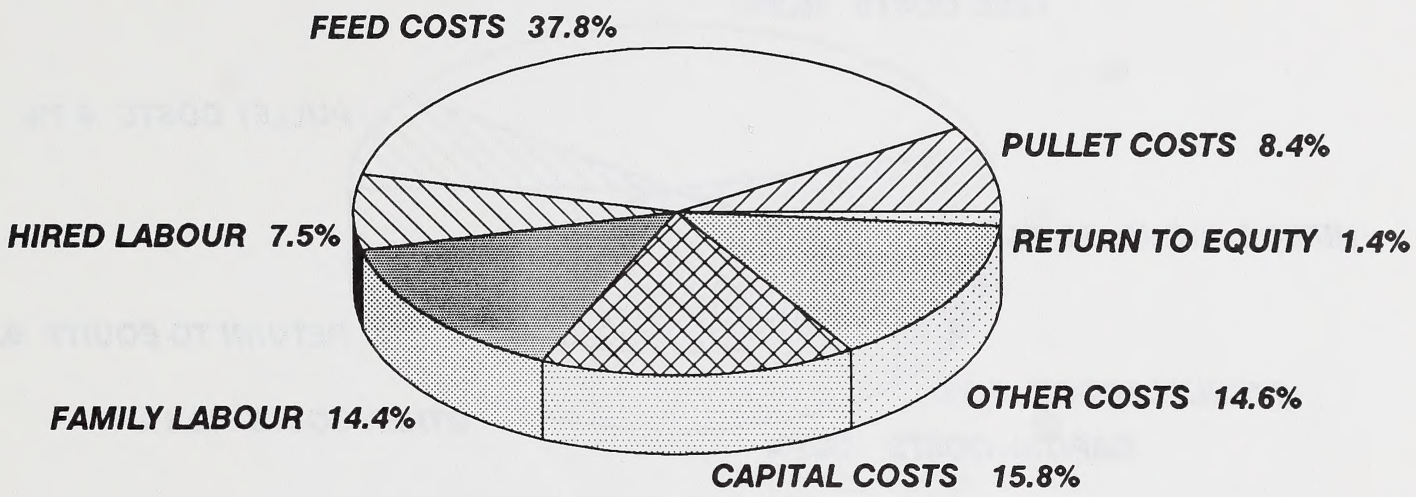

FIGURE 2: INPUT COSTS AS PER CENT OF GROSS INCOME OF HATCHING EGG FARMS IN ALBERTA, 1986

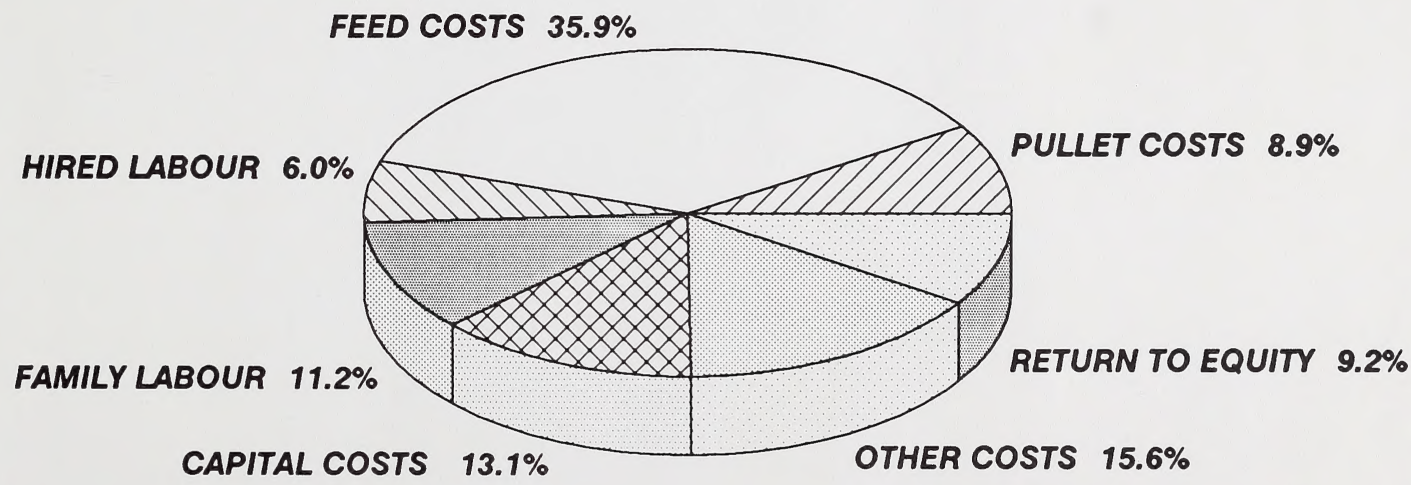


FIGURE 3: INPUT COSTS AS PER CENT OF GROSS INCOME OF HATCHING EGG FARMS IN ALBERTA, 1987

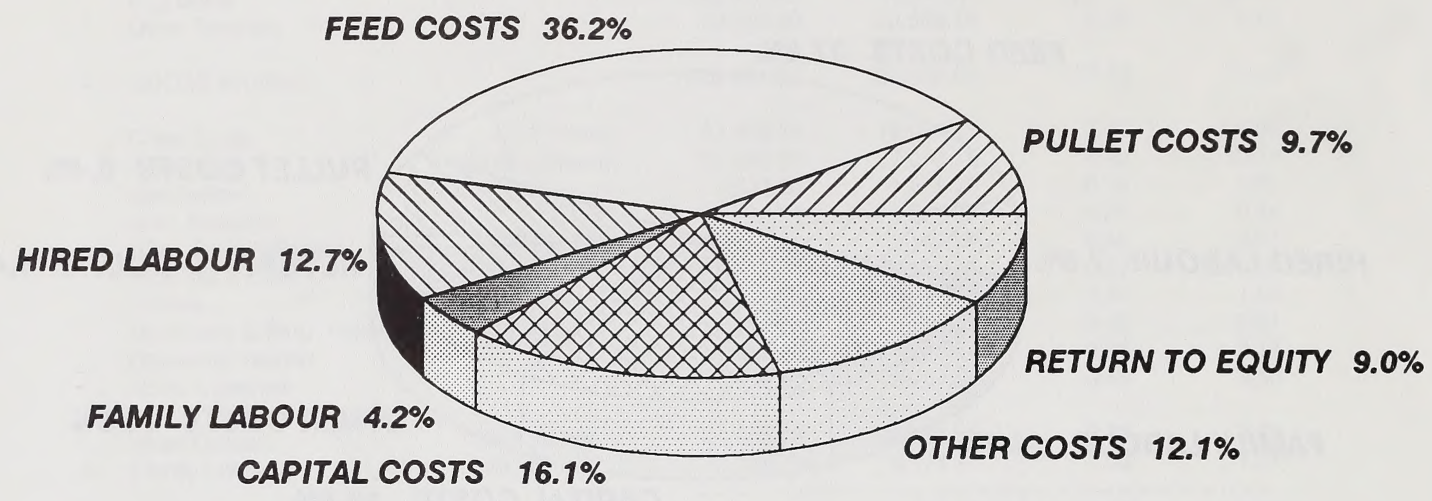



